\title{
The Threat of a Nuclear- Armed North Korea and the Possibility of Solutions
}

\section{Zain Maulana}

School of International Studies Flinders University, Australia

Email:maulana.zain@yahoo.com

\begin{abstract}
This article tries to describe the threat of North Korea nuclear to regional and international security. North Korea Nuclear Proliferation is open the possibility of an arms race, even nuclear war in the region. Moreover, North Korea technology's ability in produce nuclear weapon will improve the spread of the weapons, both towards other countries or foreign actors. It needs some regional policy innovation to prevent nuclear proliferation in the region.

Keywords: North Korean Nuclear, Security Threats, International Policy
\end{abstract}

\begin{abstract}
Abstrak
Artikel ini memberi gambaran tentang ancaman nuklir Korea Utara terhadap keamanan regional maupun internasional. Proliferasi nuklir Korea Utara membuka kemungkinan bagi hadirnya perlombaan senjata, bahkan perang nuklir, di kawasan. Lebih auh, kemampuan teknologi Korea Utara dalam memproduksi senjata nuklir akan meningkatkan penyebaran senjata ini, baik terhadap negara lain maupun terhadap aktor di luar negara. Dibutuhkan sejumlah terobosan kebijakan regional untuk mencegah proliferasi nuklir di kawasan.

Kata Kunci: Nuklir Korea Utara, Ancaman Keamanan, Kebijakan Internasional
\end{abstract}

\section{INTRODUCTION}

The Democratic People's Republic of Korea (DPRK) is an authoritarian state controlled by the Kim regime for decades. In 2012, the government has delivered a political message to the world that North Korea has already attained the status of a politically, ideologically, and militarily powerful state, while it seeks to be recognized by the world as a nuclear state (Nanto and Manyin, 2010: 9). For North Korea, nuclear armament plays a significant role as a source of political status as well as strengthening the regime leadership. In this regard, however, 'nuclear technology, is inherently dual-use: 'Atoms for Peace' immediately suggests the possibility of 'Atoms for War' (F. Lehman II, 1993: 6).

Observations of the state tend to show that the possibility to use nuclear weapons is high. Nucleararmed North Korea has increased vulnerability for both regional and international security. The possibility of an arms race or even nuclear war is also considered. Furthermore, the capability of the DPRK in nuclear technology is likely to increase the spread of nuclear weapons to other state and non-state actors. To deal with these problems, some measures are possible to realize denuclearization in the Korean peninsula whether through economic sanctions, international regime or even military intervention.

Regarding these matters, this article attempts to discuss why nuclear-armed North Korea poses a threat to regional and international security. It begins with a brief explanation of the DPRK nuclear armament policy. The next section will discuss the threats of the DPRK nuclear-armed for both regional and international security. In addition, discussion of the preferred option for the international community to deal with a nuclear-armed North Korea will be addressed in the final section. 


\section{ANALYSIS}

\section{NORTH KOREAN NUCLEAR POLICY}

The DPRK is a communist-authoritarian country led by Kim's regime. For decades, North Korea was subject to embargo and isolated by a majority of countries in the world especially by the United States and European countries. Generally, the DPRK has a less significant role in both international economics and international politics. Nevertheless, the nuclear proliferation policy issued by the government absolutely increased the significance of the state at the international level, mainly with regard to security and peace issues.

In this regard, there are several reasons underlying the nuclear policy. First, the policy to begin a nuclear program aims to fulfill national energy needs. This policy is important for the state budget in order to support a national program of economic development. In spite of this, the energy goal is still debatable, because of the lack of information regarding the nuclear program. Second, the nuclear proliferation is aimed at increasing the political bargaining position either at regional or international level. Obviously, the DPRK nuclear proliferation issue has increased the political leverage of the communist state, at least, in the region. Some major countries such as United States, China, Russia and some of European States have been discussing the issue at international level. Many solution packages offered to the DPRK government consist of economic and political assistance in order to discontinue the nuclear program.

\section{WHY A NUCLEAR-ARMED NORTH KOREA IS DANGEROUS}

Nuclear-armed North Korea is clearly a threat to both regional and international security. The threats are related to three critical issues. First, nuclear-armed North Korea is a threat for regional and international security because nuclear proliferation is considered to have occurred in a 'rogue state' or 'untrustworthy regime' (Ayson and Taylor, 2004: 269). The Kim regime is considered to be dangerous because their authoritarian power makes them likely to use nuclear weapons. In addition, North Korea frequently shows provocative action in the region regarding nuclear and missile forces with tested of nuclear weapons in October 2006 and May 2009 (Nanto and Manyin, 2010: 4).

Second, North Korea has been labeled as one of the 'axis of evil' states, with Iran and Iraq that pose 'a grave and growing danger' to international security (Howard, 2004: 806). In their article, Proliferation ring; New Challenges to the Nuclear Nonproliferation Regime, Chaim Braun and Christopher F. Chyba, argue that North Korea is a latent proliferation country, which means this country has capabilities to proliferate nuclear arms and is likely to export its technology to other states such as Pakistan and Libya (Braun and Chyba, 2004: 5-6). In 2002, North Korea appears to have turned to Pakistan, with its fully developed uranium enrichment program. 'This apparently led to a missile for enrichment technology barter deal between Pakistan and North Korea, a benchmark event in the global proliferation enterprise' (Braun and Chyba, 2004: 12). Thus, a list of reasons why North Korea with nuclear capacity is dangerous includes, most importantly, proliferation through sales and support to other unreliable states.

In this regard, nuclear proliferation in North Korea will stimulate a missile and nuclear weapons supply chain across nations and it means that international security is threatened with nuclear war. Furthermore, considering the terrible economic conditions of the country, North Korea is likely to sell dangerous weapons to any customers who will pay hard currency, because they need a sustainable cash flow to finance their national project (Armacost, Okimoto, and Shin, 2003: 2). Besides that, the spread of nuclear weapons around the world is increasing the likelihood of terrorist groups to getting their hands on nuclear weapons.

In today's war waged on world order by terrorists, nuclear weapons are the ultimate means of mass devastation. Furthermore, terrorist groups with nuclear weapons are conceptually outside the bounds of a deterrent strategy and present difficult new security challenges (Shultz, Perry, Kissinger and Nunn, 2007: 1). 
Hence, the efforts to denuclearize North Korea are critically important to deter the deployment of nuclear weapons in many other 'rogue states' and to the non-state actors such as militants in Pakistan, Iraq and many others.

Third, a nuclear-armed North Korea may possibly turn to facilitating the arms race in the region. Barry Buzan argues that most attempts to define the arms race are rooted in the action-reaction model. The basic proposition of the model is that states strengthen their armaments because of the threats they perceive from other states (Buzan, 1978: 76). In this regard, North Korea's neighbour states such as Japan, South Korea, and possibly Taiwan and other Asian countries are likely to develop their own nuclear deterrence and ballistic missile capabilities to ensure security from North Korean threats (Demetriou, 2009: 8). If it happens, the arms race will obviously exist in the region.

\section{WHY WAR IS NOT PREFERRED}

The most striking policy in dealing with the issue is the possibility to attack North Korea, particularly led by the United States and the allies. Regarding this option, there are four assessments that show the option to attack North Korea is a very difficult and risky solution. The first assessment of the policy relates to the cost of the policy. Some scholars, Robert Ayson and Brendan Taylor, for instance, argue that the cost to attack North Korea may be lower than estimated for the United States (Ayson and Taylor, 2004: 271 272). The U.S. military superiority over North Korea will increase the possibility to win the battle and reach the main target, being to change the Kim regime. In addition, the absence of a North Korean major power patron in the military aspect is the key factor that increases opportunities to change the regime by military operation. Operations in Iraq and Afghanistan are obvious examples that show the lack of a major power patron makes success more likely, more quickly and easily than if they enjoy such support (Ayson and Taylor, 2004: 271-272). Nevertheless, conditions differ between North Korea and Afghani- stan as well as Iraq. North Korea has close relations with one powerful state, China, politically and economically, although China is not a power patron of North Korea. This relationship is critical for North Korea to deal with international pressures regarding nuclear proliferation.

Secondly, the question to be answered is regarding the effectiveness of military intervention to shut down nuclear proliferation and to change the authoritarian regime. The Kim regime is considered to be the main problem of the North Korea issue that triggers the emerging of nuclear forces. It implies that the solution to deal with North Korean nuclear proliferation is to address regime change toward democracy in North Korea. Yet, there is no guarantee that attacking North Korea will automatically transform the political system. North Korea is different from other countries that have been occupied by the U.S such as Iraq and Afghanistan. While Iraq and Afghanistan are countries less controlled by central government as well as the spread of separatism or terrorism movements in many parts of the nation, North Korea is an authoritarian state with strong control from central government and high leverage from the regime. This means that it is inappropriate to generalize the effectiveness of U.S. intervention from previous missions and to expect that it will occur automatically in North Korea.

Thirdly, the U.S. and its allies will face huge challenges regarding any attack on North Korea. The challenges will come from China that will likely reject an option for military intervention to North Korea. Several reasons to reject the intervention are involved. China is North Korea's closest ally, and the largest trading partner in provision of food, fuel and industrial machinery (Nanto and Manyin, 2010: 1). In addition, war will cause destabilization in the Korean peninsula and it is incompatible with China's interest. Although, China's interest in stability on the Korean peninsula is linked to U.S. interest in denuclearization, China's government is unlikely to choose military intervention, even as 'the least-worst option, delivering a statement that diplomacy is the preferred solution to every provocation by North Korea' (Nanto 
and Manyin, 2010: 4). Recently, as the most powerful Country in Asia, China is concerned to maintain strong leverage in that region and will not allow any other major power to change the domination. 'China has wide influence over North Korea but elects not to use it in order to ensure that the North Korean issue continues to complicate U.S. regional strategy and undermine the U.S. position in Asia' (Nanto and Manyin, 2010: 4).

On the other hand, the challenges to attacking North Korea are Japan and South Korea. Although, both states are U.S. allies, they are unlikely to prefer war because it may increase the vulnerability of their national security with the use of chemical weapons as a retaliatory strike from North Korea (Ayson and Taylor, 2004: 265). Both countries acknowledge that if the war occurs, the U.S. government will deploy military bases in both states. Thus, it is automatically to involve Japan and South Korea in that war. Hence, without support from Japan and South Korea, as the closest U.S. allies and North Korea's neighbours it will be very difficult to destroy the nuclear facilities effectively.

The last assessment looks at the consequences of a military attack on North Korea. Military attack will have particular impact on the nation and also the wider parties. Military attack on North Korea has potential to become a widespread war in the region. In the war, North Korea is very likely to use Weapons of mass Destruction (WMD) or even nuclear weapons in retaliation to the attack. The weapons may be the most effective force for North Korea because they have no adequate conventional military forces to deal with the U.S. military forces. If North Korea used WMD or nuclear weapons the consequences of the war will be catastrophic for the region. In addition, even if the attack is to destroy the North Korean nuclear proliferation facilities, the impact will be worse because of the spread of radioactivity particularly to South Korea, Japan and parts of China (Carter and Perry, 2002: 275). Hence, the option to attack North Korea is less urgent and counterproductive for many parties. This option will be very difficult, if not impossible, because it is not supported by the three major important states in the region; China, Japan and South Korea.

\section{INTERNATIONAL REGIME DILEMMAS}

Delivering pressure to North Korea through international regimes such as the U.N. Security Council or International Atomic Energy Agency (IAEA) to denuclearize North Korea is very difficult. Basically, the main functions these regimes to control uranium for energy use only and to ensure the absence of nuclear weapons in particular states, the IAEA, for instance, 'was created to administer safeguards over peaceful nuclear facilities around the world' (Nye Jr, 1992: 1294). Yet, the dilemma is that those institutions cannot intervene in a sovereign state. Regarding nuclear-armed North Korea, in the 1970s, this country signed various agreements with the IAEA, and in 1985 North Korea signed the Non-Proliferation Treaty (NPT). However, North Korea began construction work on a gas-graphite reactor and this reactor was the centre of North Korea's nuclear problem because the reactor extracted plutonium which is the key material for nuclear weapons. 'While North Korea insisted that the reactor was for energy, there was no sign of any steps to channel electricity from the reactor facilities to the rest of the country. In addition, by 1991 both the Soviet KGB and the American CIA had concluded that a nuclear weapons program was indeed at an advanced stage' (McCormack, 2004: 151-152).

The dilemma for the international regimes is the difficulty in compelling a state to obey the agreement. North Korea's disobedience shows that the national interests of a state determine its action more than pressure from outside. Although North Korea had signed the international agreement and was pressured by the international community particularly the United States, the Kim government ignored it and continued the nuclear proliferation program. Furthermore, to obtain nuclear weapons, rather than to obey the agreement, North Korea instead announced that they would not accept the additional inspections proposed by the IEAE to resolve concerns about possible violations. Instead, 'one year after the United 
nations Security Council declared at the head of state level that proliferation was a threat to international peace and security, Pyongyang announced that it was withdrawing from the NPT' (F. Lehman II, 1993: 1-4). This indicates the difficulty for international regimes in attempting to compel a state when the international treaty has to come head to head with the power of state interest.

Therefore, using the IAEA and U.N. as instruments to pressure North Korea is 'time wasting' policy.

Rather than obey the international regime's proposal, the North Korea government instead claims that the international regimes are political tool of the United States (Hassig and Kongdan Oh, 2005: 6).

\section{STRONGER ECONOMIC SANCTIONS: PREFERRED SOLU- TION?}

The United States and international community attempt to look for solutions to deal with the North Korea nuclear issue. Several policies are possible to stop the proliferation, but each policy has to consider the challenges and the consequences whether at domestic, regional or international level. In this regard, the international community can deliver economic sanctions as an instrument to pressure North Korea to discontinue nuclear proliferation. The sanctions can be economic embargo, export control or freezing of state assets. The sanctions are expected to weaken the state economy in order to change its nuclear proliferation policy. Economic instability automatically pushes the state to be more compliant and easier to bring into the negotiation process, to discuss the issue and to look for a better solution, because the economic embargo and freezing of assets will exacerbate economic conditions and make it more likely that the state will follow the international proposal.

Obviously, the international community has delivered the sanctions to North Korea through the United Nations, but so far, the sanctions are not working effectively to denuclearize North Korea. In spite of the fact that, the US and UN sanctions have banned shipments of luxury goods to North Korea, and trade with South Korea, Japan, and the United States has virtually stopped (Nanto and Manyin, 2010: 2), China's leverage in North Korea is remains strong and important regarding supply of food, fuel, industrial machinery and even political support to the regime, in order to keep stability on the Korean peninsula. Furthermore, in 2009, China planned to create a major new development zone called the Tonghua - Dandong Economic Zone along the North Korean border, aimed at boosting trade (Nanto and Manyin, 2010: 12). This shows that China plays a fundamental role in this issue, and the international community recognizes that the consistent engagement of China in the implementing of the sanctions is very important.

Regarding this option, the international community can tightly control export activity related to the stuff of nuclear technology. Export activity is not only conducted by the state but also by a proliferating network in the private sector. 'North Korea and Libya reportedly used private firms to purchase centrifuge components through Dubai, with assistance from the Turkish electrical components firm Elektronik Kontrol Aletleri (EKA), Sri Lankan businessman Buhary Syed Abu Tahir, and the A.Q. Khan network' (Braun and F. Chyba, 2004: 15).

Basically, controlling export of nuclear related components is important because the ability to create nuclear weapons is highly dependent on technological raw materials to transform the uranium to weapons grade. Mostly, the either as latent proliferation, firsttier nuclear proliferation or second-tier proliferation (Braun and F. Chyba, 2004: 5), states cannot produce all the raw materials for nuclear weapons and in some parts, are highly dependent on supply from other parties, either other nuclear states or private companies. Hence, this measure is critical and has high potential to discontinue nuclear proliferation in North Korea or at least, decelerate the spread of nuclear weapons around the world.

However, economic sanctions will cause economic collapse in North Korea. This condition will lead to starvation and a flood of refugees from North Korea 
to other neighbouring countries such as China and South Korea. These matters are an obstacle to implementing economic sanctions effectively. For instance, China is continuing economic assistance to North Korea by providing food and energy assistance. This policy can be seen as an insurance that 'Beijing remits regularly to avoid paying the higher economic, political, and national security costs of a North Korean Collapse, a war on the peninsula, or the subsuming of the North into the South' (Braun and F. Chyba, 2004: 7). While implementing sanctions to prevent the development of nuclear weapons, humanitarian aid should also be provided by the international community to North Korean people. This aid is to avoid increasing starvation and the massive migration of refugees to other neighbouring countries. Thus, it is very important for the international community to create an intensive dialog with China in order to look for the best form of economic sanctions for North Korea by considering the social impacts, starvation and flood of refugees, of this sanctions.

\section{CONCLUSION}

All in all, nuclear proliferation in North Korea is an obvious threat for regional and international security. It poses threats because North Korea has the potential to export nuclear weapons technology to other states, and of course the spread of nuclear weapons around the world will increase the possibility of non-state actors such as terrorist groups gaining possession of missiles and nuclear weapons. Moreover, the existence of nuclear weapons can cause an arms race in that region, and also the authoritarian Kim regime is highly likely to use nuclear weapons in a war.

This problem needs an effective solutions with consideration of the challenges and the consequences, such as the possibility of starvation in North Korea, the flood of refugees, the instability of the Korean peninsula and also the spread of nuclear radioactivity to other countries in that region. To deal with the problem, war is not preferred for many parties in the region, nor for China or the U.S. closest allies, Japan and South Korea. This option is cannot work effec- tively without major support from those countries.

In addition, regarding the impact, attacking North Korea is very risky and makes many parties highly vulnerable whether North Korean citizens, states in the region or even the U.S and its allies. While attacking North Korea will have great impact, military intervention to change the regime and to freeze nuclear proliferation is likely to be extremely difficult. Besides that, pressure on North Korea through international institutions is also ineffective, because the North Korean government can reject the institution's proposal or inspections of the nuclear site.

Presently, the international community can strengthen economic sanctions by engaging China more deeply in implementing the policy. This measure is more do-able and appropriate, at the moment, for international community, in order to denuclearize the Korean peninsula or at least, to slow down the nuclear proliferation with minimum impact.

\section{BIBLIOGRAPHY}

Andemicael, Berhanykun and John Mathiason. 2005. Eliminating Weapons of Mass Destruction; Prospects for effective International Verivication. England: Palgrave Macmillan.

Ayson, R and B. Taylor. 2004. Attacking North Korea: Why War Might be Preferred. Comparative Strategy, 23 (3).

Braun, Chaim and Christopher F. Chyba. 2004. Proliferation Rings; New Challenges to the Nuclear Non-proliferation Regime. International Security, Vol. 29, No. 2.

Buzan, Barry. 1987. An Introduction to Strategic Studies; Military Technology and International Relations. New York: International Institute for Strategic Studies.

Carter, Asthon B. and William J. Perry. 2002 Back to the Brink. Washington Post.

Demetriou, Danielle. 2009. Japan Should Develop Nuclear Weapon To Counter North Korea Threat. The Telegraph.

F. Lehman, Ronald II. 1993. Implications of a North Korean Nuclear Weapons Program. Lawrence Livermore national laboratory.

Hassig, Ralph C., Kongdan Oh. 2005. The Twin Peaks of Pyongyang. Foreign Policy Research Institute, Elsevier.

Howard, Peter. 2004. Why Not Invade North Korea? Threats, Language Games, and U.S. Foreign Policy. International Studies Quarterly 48.

John H, Nuckolls. 1995. Post-Cold War nuclear dangers: Proliferation and terrorism. Science Vol. 267, The American Association for the Advancement of Science.

Klare, Michael. 1995. Rogue States and Nuclear Outlaws; America's Search for a New Foreign Policy. United States: Harper Collins. 
74 JURNAL HUBUNGAN INTERNASIONAL

VOL. 3 NO. 1 / APRIL 2014

McCormack, Gavan. 2004. Target North Korea; pushing North Korea to the brink of nuclear catastrophe. Random House of Australia.

Nanto, Dick K. and Mark E. Manyin. 2010. China-North Korea relations. Congressional Research Service.

S. Nye, Jr, Joseph. 1992. New Approches to Nuclear proliferation Policy. Science, Vol. 256 (5061).

Shultz, George P., William J. Perry, Henry A. Kissinger and Sam Nunn. 2007. A World Free of Nuclear Weapons. The Wall Street Journal. 